\title{
10. BACTERIAL PROFILES IN DEEP SEDIMENTS OF THE SANTA BARBARA BASIN, SITE 8931
}

\author{
B.A. Cragg, ${ }^{2}$ R.J. Parkes, ${ }^{2}$ J.C. Fry, ${ }^{3}$ A.J. Weightman,${ }^{3}$ J.R. Maxwell, ${ }^{4}$ M. Kastner,${ }^{5}$ \\ M. Hovland, ${ }^{6}$ M.J. Whiticar, ${ }^{7}$ J.C. Sample, ${ }^{8}$ and R. Stein ${ }^{9}$
}

\begin{abstract}
Bacterial depth profiles were obtained from high-organic-load sediments (water depth $538 \mathrm{~m}$ ) to a depth of $68.28 \mathrm{~m}$ below seafloor. Using the Acridine Orange Direct Count (AODC) technique, near-surface bacterial populations were $1.27 \times 10^{\circ} \mathrm{cells} /$ $\mathrm{cm}^{3}$. Numbers of bacteria decreased rapidly to $4.77 \times 10^{6} \mathrm{cells} / \mathrm{cm}^{3}$ at $12 \mathrm{mbsf}$ and then more slowly to $2.51 \times 10^{6} \mathrm{cells} / \mathrm{cm}^{3}$ at $68.28 \mathrm{mbsf}$ (505-fold decrease). Dividing cells represented approximately $10 \%$ of the total count but decreased at a greater rate (850-fold). There was an abrupt change in the rate of total bacterial population decrease at approximately 13 mbsf. Bacterial numbers were strongly correlated $(P<<0.002)$ with total organic carbon. Near-surface concentrations of organic carbon rapidly decreased from approximately $3.6 \%$ to $2.0 \%$ at 13 mbsf, and thereafter remained at $1.5 \%-2.0 \%$ to the base of the core at $68.28 \mathrm{mbsf}$, indicating a high level of recalcitrance. The changes in the rate of bacterial population decrease with depth may be a response to increasingly recalcitrant organic carbon. High levels of methane $(4100 \mu \mathrm{mol} / \mathrm{L})$ were found at $9.0 \mathrm{mbsf}$, although the maximum concentration present in the sediment at this site may be in an unsampled horizon above this depth. At greater depth, methane concentrations were still high $(>1000 \mu \mathrm{mol} / \mathrm{L})$, and although this area has many seeps of oil and gas, the $\mathrm{C}_{1} / \mathrm{C}_{2}$. ratios indicate a biogenic rather than a thermogenic source. This work represents the first detailed microbiological analysis of deep sediment layers from the Santa Barbara Basin.
\end{abstract}

\section{INTRODUCTION}

Bacteria play a central role in the degradation and selective preservation of organic matter in marine sediments and are thus intimately involved in biogeochemical cycling of elements (Jørgensen, 1983). Their presence and activity in surface sediments has long been accepted (Novitsky and Karl, 1986; Jørgensen et al., 1990). At the interface between the water column and the sediment surface, detrital microaggregates will accumulate in an oxic, or suboxic, environment, producing a favorable habitat for bacterial growth (Lochte and Turley, 1988; Turley and Lochte, 1990). Geochemical evidence (chemical changes in pore water, kerogen production, concretion formation, etc.) has suggested that bacterial populations remain active at considerable depths (Krumbein, 1983); some early evidence of the existence of such populations, based only on enrichment of viable bacteria exists (Rittenberg, 1940; ZoBell, 1958; Davis, 1967). More recently, with improved techniques, there have been a number of reports on the cultivation of bacteria from 200 meters below seafloor (mbsf) (Oremland et al., 1982; Belyaev and Ivanov, 1983; Bianchi, 1986), and work on deep aquifers has shown the presence of bacterial populations in sediments over $1000 \mathrm{~m}$ deep (White et al., 1983; Balkwill, 1989; Erlich and Ghiorse, 1989; Phelps et al., 1989; Chapelle and Lovley, 1990; Fliermans et al., 1993).

'Kennett, J.P., Baldauf, J.G., and Lyle, M. (Eds.), 1995, Proc. ODP, Sci. Results, 146 (Pt. 2): College Station, TX (Ocean Drilling Program).

'Department of Geology, University of Bristol. Bristol BS8 IRJ, United Kingdom.

${ }^{3}$ School of Pure and Applied Biology, University of Wales College of Cardiff, P.O. Box 915, Cardiff CFI 3TL, United Kingdom. dom.

Department of Chemistry, University of Bristol, Bristol BS8 IRJ, United King-

scripps Institute of Oceanography, Geological Research Division A-012, La Jolla. CA 92093, U.S.A.

-Statoil, P.O. Box 300, N-4001 Stavanger. Norway.

'SEOS, University of Victoria, P.O. Box 1700, Victoria, B.C, V8N I YU, Canada.

*Department of Geological Sciences, California State University, 1250 Bellflower Blvd., Long Beach, CA 90840 , U.S.A.

"Alfred-Wegener Institut für Polar und Meeresforschung, Columbusstrasse, D-2850 Bremerhaven, Federal Republic of Germany.
In the marine environment, evidence for low levels of anaerobic bacterial methanogenesis and sulfate reduction has been reported in sediments to $167 \mathrm{mbsf}$ in the Gulf of Mexico and the North Atlantic (Whelan et al., 1986; Tarafa et al., 1987). In a comprehensive study of high-organic-load sediments from the Peru Margin, Cragg et al. (1990) and Parkes et al. (1990) have described significant levels of bacterial sulfate reduction and methanogenic activity to $80 \mathrm{mbsf}$, and significant bacterial populations associated with low levels of activity have been reported to $500 \mathrm{mbsf}$ in the Japan Sea (Cragg et al., 1992; Getliff et al., 1992; Parkes et al., 1994). Most recently, examination of sediments from sites of considerably lower oceanic productivity and, consequently, much lower sediment organic carbon concentrations has demonstrated the continued presence of significant numbers of bacteria, associated with low levels of bacterial activity, in sediments to $100 \mathrm{mbsf}$ in the Lau Basin (Cragg, 1994) and to $310 \mathrm{mbsf}$ in the Eastern Equatorial Pacific (Cragg and Kemp, in press).

The Santa Barbara Basin (SBB) sediments have long been recognized as providing a detailed index of recent environmental climatic history (Soutar and Crill, 1977). The surficial sedimentation rate is approximately $4 \mathrm{~mm} / \mathrm{yr}$ (Schimmelmann et al., 1990), with sediment containing total organic carbon concentrations of 2-8 wt\% laid down and preserved in the form of millimeter-scale laminae thought to be related to an annual cycle of oxygen replenishment and depletion in bottom waters (Reimers et al., 1990; Schimmelmann and Tegner, 1991). Bacterial degradation of organic matter settling out from the highly productive overlying surface waters reduces the oxygen content of the deepest waters, resulting in dysaerobic to anaerobic conditions with less than $0.1 \mathrm{~mL} / \mathrm{L}$ dissolved oxygen (Kennedy and Brassell, 1992). This lack of oxygen inhibits the development of benthic animal populations and bioturbation of the surface sediments is prevented (Soutar and Crill, 1977; Savrda et al., 1984; Kennedy and Brassell, 1992). Disturbance is further reduced by the growth of bacterial mats covering some $20 \%$ of the sediment surface, coincident with the highest levels of total organic carbon (Grant, 1991), consisting predominantly of the filamentous sulfur-oxidizing Beggiatoa spp. with some iron-oxidizing bacteria (Soutar and Crill, 


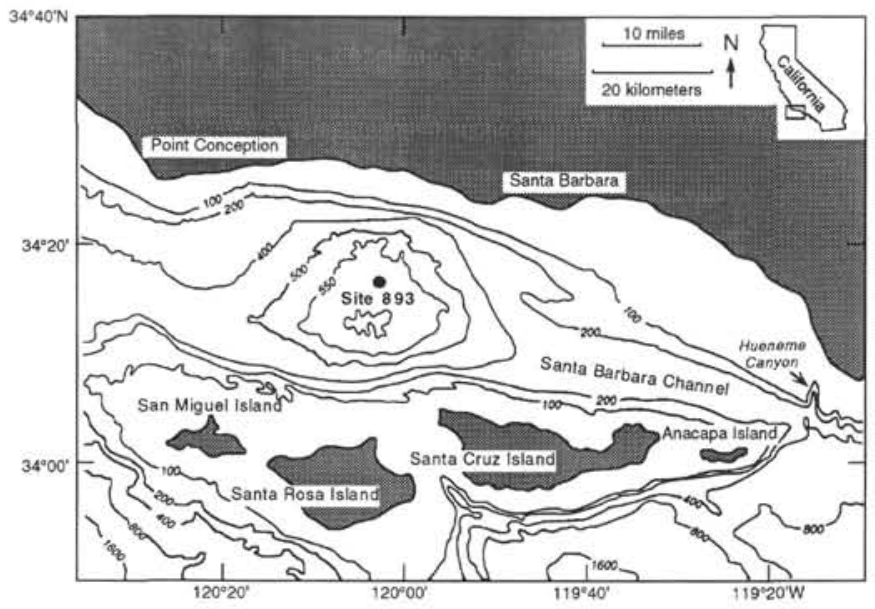

Figure 1. Map of the Santa Barbara Basin showing the location of Site 893. Contours are in meters. Redrawn from Kennett, Baldauf, et al. (1994).

1977; Reimers et al., 1990). The presence of a sediment that is fully anaerobic to the surface is unusual (Soutar and Crill, 1977), and the lack of bioturbation will result in deposited organic carbon encountering only strictly anaerobic processes at the sediment surface before being incorporated into laminae. A considerable amount of work has been published on SBB sediments, although this has principally focussed on sediment geochemistry and cores of less than $75 \mathrm{~cm}$ (Soutar and Crill, 1977; Lange et al., 1987; Reimers et al., 1990; Bernhard and Reimers, 1991; Grant, 1991; Schimmelmann and Tegner, 1991; Schmidt and Reimers, 1991; Kennedy and Brassell, 1992; Schimmelmann et al., 1992). Other investigators have obtained samples up to 9 mbsf using piston and gravity cores for the purpose of determining sedimentary structures and marker layers (Thornton, 1986; Schimmelmann et al., 1990), sulfur chemistry (Schimmelmann and Kastner, 1993), and bacterial methanogenesis and methane oxidation rates (Kosiur and Warford, 1979; Doose and Kaplan, 1981).

Ocean Drilling Program (ODP) Site $893 \quad\left(34^{\circ} 17.0^{\prime} \mathrm{N}\right.$, $120^{\circ} 02.2^{\prime} \mathrm{W}$ ) is on the floor of the SBB (Fig. 1) at $538 \mathrm{~m}$ water depth (Kennett, Baldauf, et al., 1994). Sediments in this area are rich in organic carbon and methane (probably biogenic), with overlying water which is anoxic or suboxic $\left(<0.1 \mathrm{~mL} / \mathrm{L} \mathrm{O}_{2}\right)$. Sediment core samples were obtained from this site for a study which is, to our knowledge, the first investigation of bacterial populations and biomass in deep layers of SBB sediments.

\section{MATERIALS AND METHODS Shipboard Handling}

\section{Bacterial Analysis}

Samples were removed from 25 core sections, between 0 and $68.28 \mathrm{mbsf}$, of Hole $893 \mathrm{~B}$. The surface $1-\mathrm{cm}^{3}$ sample was taken from the loose slurry present at the top of the first core using a sterile (autoclaved) 5-mL syringe from which the luer end had been removed. The sample was ejected directly into a tared serum vial containing 9 $\mathrm{mL}$ of filter-sterilized $(0.2 \mu \mathrm{m}) 4 \%$ formaldehyde in artificial seawater. For all other samples, immediately after a core was cut into 1.5$\mathrm{m}$ sections on the outside catwalk, a thin layer of sediment was removed from the section end using a sterile scalpel to expose an uncontaminated surface. A $1-\mathrm{cm}^{3}$ sample was then taken with a sterile syringe as above and the samples were preserved as before.

\section{Headspace Methane}

Samples $\left(5 \mathrm{~cm}^{3}\right)$ from Hole $893 \mathrm{~B}$ were removed from 9 core sections on the catwalk between 1.5 and 68 mbsf using a calibrated cork borer. The sediment was placed in a $21.5-\mathrm{cm}^{3}$ glass serum vial and crimp-sealed. The vial was heated to $60^{\circ} \mathrm{C}$ in an oven for $30 \mathrm{~min}$ before a $5-\mathrm{cm}^{3}$ gas sample was removed for analysis by gas chromatography (Kennett, Baldauf, et al., 1994).

\section{Laboratory Handling}

\section{Direct Microscopic Observations}

Acridine Orange staining and microscopic observations were based on the general recommendations of Fry (1988) with minor modifications. Preserved samples were vortex mixed, and between 5 to $10 \mu \mathrm{L}$ were added to $10 \mathrm{~mL}$ of filter-sterilized $(0.1 \mu \mathrm{m}) 2 \%$ formaldehyde. Acridine Orange $(50 \mu \mathrm{L})$ was added to give a final concentration of $5 \mathrm{mg} / \mathrm{dm}^{3}$. After $3 \mathrm{~min}$, the solution was filtered through a 25-mm diameter Nucleopore black polycarbonate membrane (Appleton Woods, Birmingham, U.K.) of $0.2-\mu \mathrm{m}$ pore size. The filter was rinsed with an additional $10 \mathrm{~mL}$ of filter-sterilized $2 \%$ formaldehyde and mounted in a minimum amount of paraffin oil under a coverslip. Triplicate membranes were prepared from each sample.

Mounted membrane filters were viewed under incident illumination with a Zeiss Axioskop microscope fitted with a 50-W mercuryvapor lamp, a wide-band interference set for blue excitation, a 100x (numerical aperture $=1.3$ ) Plan Neofluar objective lens, and $10 \times$ eyepieces. Bacterially-shaped green or red fluorescing objects were counted. Cells on or off particles were counted separately, and the numbers of those on particles were doubled in the final calculations to account for cells hidden from view by particles (Goulder, 1977). Dividing cells (those with a clear invagination) and divided cells (pairs of cells of identical morphology) were also counted. A minimum of 200 fields of view were counted on each membrane. Where replicate $\log _{10}$ counts differed by more than $0.5 \log _{10}$ units a fourth membrane was prepared. The detection limit was calculated to be I $\times 10^{5}$ cells $/ \mathrm{cm}^{3}$ (Cragg, 1994).

\section{Total Organic Carbon}

Samples for organic carbon determination were removed during a shore-based sampling meeting approximately two months postcruise. Core sections had been stored in sealed plastic tubes at $5^{\circ} \mathrm{C}$ (Kennett, Baldauf, et al., 1994) until this time. Samples were removed exclusively from Hole 893A, which was some $10 \mathrm{~m}$ laterally displaced from Hole 893B. Determination of total organic carbon was carried out on an HERAEUS CHN analyzer. Total carbon was measured from dried and ground bulk sediment samples. After washing in 10\% hydrochloric acid and drying, organic carbon was measured on the carbonate-free samples (Stax and Stein, 1993). Organic carbon (TOC wt \%) of the bulk sediment was calculated using the following equation:

$$
\text { TOC }=100-(8.333 \times \text { TC }) /\left(100 / \text { TOC }^{\prime}\right)-8.333
$$

where TC is the total carbon of the bulk sample and TOC' is the organic carbon of the carbonate-free residue.

\section{RESULTS AND DISCUSSION}

Bacteria were present in all samples to $68.28 \mathrm{mbsf}$ (Fig. 2).The near-surface total count of $1.27 \times 10^{9}$ cells $/ \mathrm{cm}^{3}$ decreased rapidly to $5.0 \times 10^{6}$ cells $/ \mathrm{cm}^{3}$ at approximately $12 \mathrm{mbsf}$ (a 254-fold decrease), 


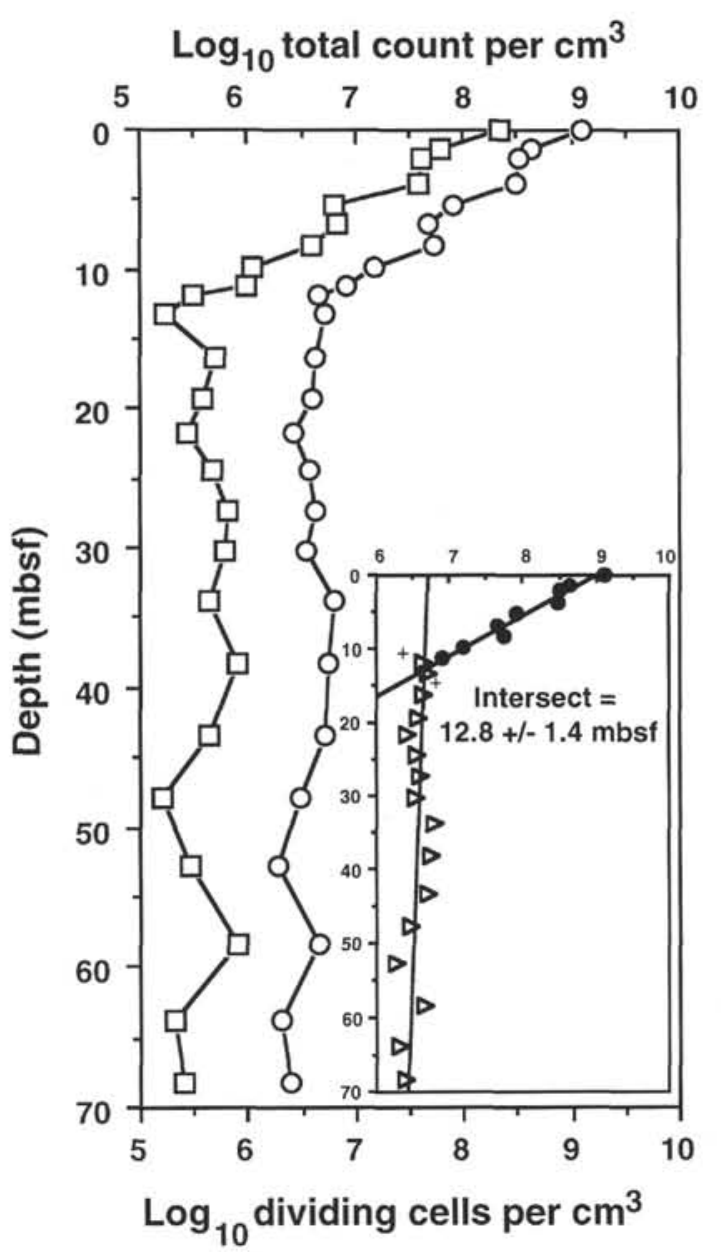

Figure 2. Depth distribution of total bacteria (open circles) and dividing/ divided cells (open squares) to $68.28 \mathrm{mbsf}$ in Hole 893B. Inset graph has the same axes and shows only total bacteria separated into two groups: upper group (solid circles) and lower group (triangles) with their respective regression lines. The two crosses indicate data points used in the construction of both regressions. The intersection was determined by simultaneous equation analysis.

and then more gradually to $2.51 \times 10^{6}$ cells $/ \mathrm{cm}^{3}$ at $68.28 \mathrm{mbsf}$, representing a 505-fold decrease in total. This overall rate of decrease is thought to be a minimum value as the near-surface sample was "soupy" and particularly difficult to sample. A layer of intact pelecypods at $0.25 \mathrm{mbsf}$ was believed to reflect the "Macoma oxygenation event" (Schimmelmann et al., 1992) indicating that APC coring had washed away approximately the top $30 \mathrm{~cm}$ of sediment (Kennett, Baldauf, et al., 1994). The near-surface total count is therefore probably an underestimate. Surficial sediment porosities in the SBB are unusually high, ranging from $86 \%$ to $95 \%$, and require specialized techniques for accurate retrieval (Soutar and Crill, 1977; Isaacs, 1985; Reimers et al., 1990). Total bacterial numbers obtained at nearby San Pedro Basin (Craven et al., 1986) using box cores that successfully captured the sediment-water interface were approximately $6.5 \times 10^{9}$ cells $/ \mathrm{cm}^{3}$ in the top $5 \mathrm{~mm}$ of sediment, some 5 times higher than reported here.

The minimum total count was $1.9 \times 10^{6}$ cells $/ \mathrm{cm}^{3}$ at $52.78 \mathrm{mbsf}$. A shift in the rate of population decrease with depth was apparent from the data, and from regression and simultaneous-equation analyses, this was calculated to be at $12.8 \pm 1.4 \mathrm{mbsf}$ (Fig. 2 inset). Above this depth bacterial populations decreased at approximately $50 \%$ per
Table 1. Comparison of direct bacterial count data at $\mathbf{0 . 0 3} \mathbf{m b s f}$ from Hole 893B with those from four other ODP sites.

\begin{tabular}{lccc}
\hline \multicolumn{1}{c}{ Source } & $\begin{array}{c}\text { Water depth } \\
(\mathrm{m})\end{array}$ & $\begin{array}{c}\text { Direct count } \\
\left(\mathrm{cells} / \mathrm{cm}^{3}\right)\end{array}$ & $\begin{array}{c}\text { Dividing count } \\
(\text { cells/cm }\end{array}$ \\
\hline Santa Barbara Basin & 576.5 & $1.27 \times 10^{9}$ & $2.15 \times 10^{8}$ \\
Eastern Equatorial Pacific & 3761 & $2.08 \times 10^{8}$ & $4.85 \times 10^{7}$ \\
Lau Basin & 2692 & $6.12 \times 10^{8}$ & $9.75 \times 10^{7}$ \\
Japan Sea & 900 & $7.82 \times 10^{8}$ & $6.35 \times 10^{7}$ \\
Peru Margin & 150 & $3.30 \times 10^{9}$ & $7.30 \times 10^{8}$ \\
\hline
\end{tabular}

Notes: Depth data from Suess, Huene, et al. (1988; ODP Leg 112 Site 681); Ingle, Suyehiro, von Breymann, et al. (1990; ODP Leg 128 Site 798); Parson, Hawkins, Allan, et al. (1992; ODP Leg 138 Site 851); and Mayer, Pisias, Janecek, et al. (1992; ODP Leg 138 Site 851). Bacterial data from Parkes et al. (1993; Charles Darwin cruise leg 38); Cragg et al. (1992; ODP Leg 128); Cragg (1994; ODP Leg 135); and Cragg and Kemp (in press; Leg 138).

meter; however, below this depth, the reduction was only $1 \%$ per meter. The age of this horizon is estimated to be $8.5 \mathrm{ka}$ at nearby Hole 893A (J. Kennett, pers. comm.). Similar changes in the rate of bacterial population decreases with sediment depth have been observed at other Pacific Ocean deep sediment sites (Cragg et al., 1990, 1992; Parkes et al., 1990; Cragg, 1994; Cragg and Kemp, in press), although the reasons for such a change are not clear and the depth at which it occurred varied between sites.

Comparisons with total counts made at other ODP sites show that near-surface counts are higher than those at less productive, deep-water sites but lower than that at the highly productive, shallow-water site in the Peru Margin (Table 1). This suggests that overlying water depth and productivity are both important in determining sediment bacterial population size (Cragg and Kemp, in press). Correlation analysis produced a significant relationship between water depth and sediment-surface population size $(R=0.911 ; N=5 ; P<0.05)$. As water depth, productivity, and near-surface organic carbon are all interrelated, the above correlation is a reflection of a general relationship.

The dividing cell numbers correlated closely with the total count $(R=0.981 ; N=25 ; P<<0.002)$, representing an average of $9.6 \%$ of the total count. This strong relationship has been observed at other sites (Cragg et al., 1990; 1992; Parkes et al., 1993; Cragg, 1994; Cragg and Kemp, in press). Near-surface numbers were $2.15 \times 10^{8}$ cells $/ \mathrm{cm}^{3}$, which decreased rapidly to approximately $12 \mathrm{mbsf}$, and thereafter more slowly to $2.52 \times 10^{5}$ cells $/ \mathrm{cm}^{3}$ at $68.28 \mathrm{mbsf}$ (Fig. 2). This represents a 850 -fold decrease, indicating that the dividing cell population decreases more rapidly than the total count. Surprisingly, the minimum population of $1.7 \times 10^{5} \mathrm{cells} / \mathrm{cm}^{3}$ was around the 12.8 mbsf change in the population depth profile (Fig. 2). Numbers of dividing cells at the near-surface $(0.03 \mathrm{mbsf})$ of $2.15 \times 10^{8}$ cells $/ \mathrm{cm}^{3}$ were relatively high although within the range observed from other sites (Table 1). Dividing cell numbers, like the total counts, show a trend of decrease with increasing overlying water depth; however, the correlation is not quite statistically significant $(P=0.1)$.

Sample depths for organic carbon determination are not entirely coincident with those for bacterial analyses, thus restricting interpretation. Average organic carbon levels over the top $1 \mathrm{~m}$ of sediment were $3.6 \%$. This compares with $4.0 \%-5.1 \%$ between 0.30 and 0.89 mbsf (ten Haven et al., 1990; Patience et al., 1990) in Peru Margin sediments, which display greater numbers of dividing cells (Table 1). Conversely, between 1.5 and $2 \mathrm{mbsf}$, the average organic carbon concentration was $2.6 \%$, compared to $1.6 \%$ over the same depth range in the Japan Sea (Ingle, Suyehiro, von Breymann, et al., 1990) which had much lower numbers of dividing cells at 0.03 mbsf (Table 1).

When calculated over the entire core length of $68.28 \mathrm{~m}$, both total count and dividing cell counts correlate significantly with organic carbon concentrations $(R=0.91$ and $R=0.86$ respectively; $N=25$; $P<<0.002)$. Similar significance has been demonstrated at other sites (Parkes et al., 1993; Cragg and Kemp, in press). The average or- 


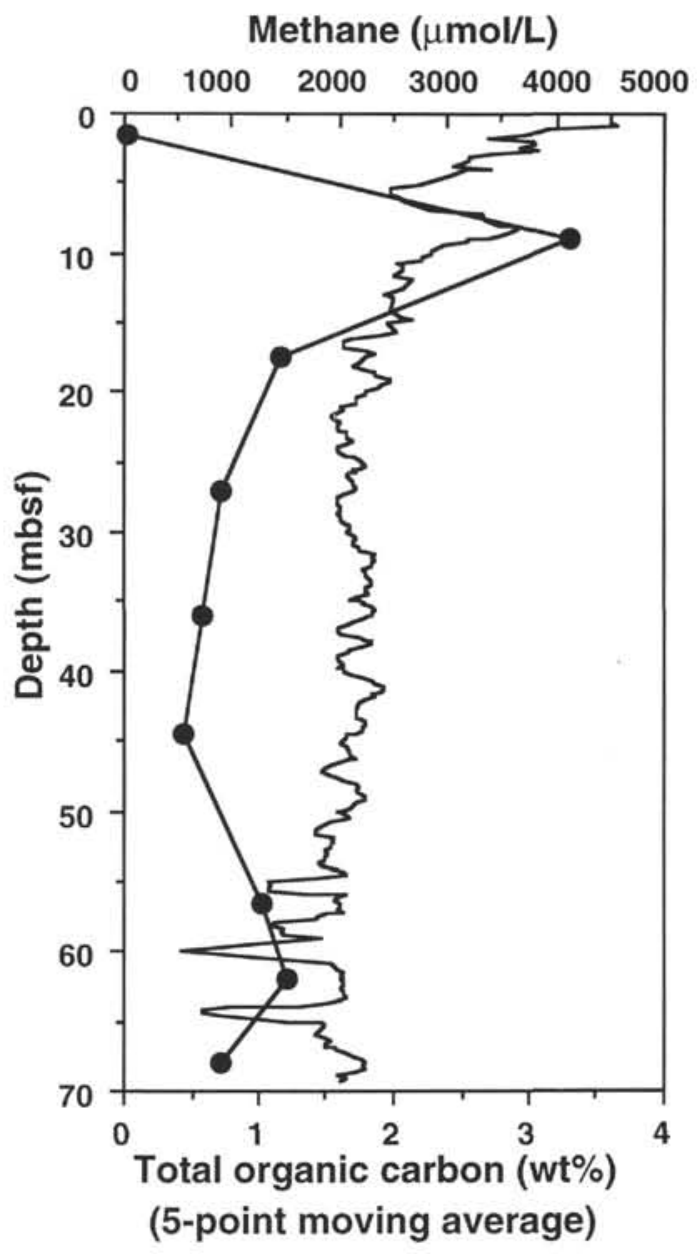

Figure 3. Depth distribution (to $68.28 \mathrm{mbsf}$ in Hole 893A) of percentage organic carbon (jagged line, no symbols. Smoothed calculation as a 5-point moving average with mean depth range for each point $=0.94 \mathrm{~m}$ ), and methane concentrations in Hole 893B (solid circles).

ganic carbon concentration in the top $1 \mathrm{~m}$ of sediment $(3.6 \%)$ compares with a previously reported range of $3 \%-4 \%$ over the top $60 \mathrm{~cm}$ of SBB sediments (Sholkovitz, 1973; Schmidt and Reimers, 1991; Schimmelmann and Kastner, 1993). Levels then decrease rapidly to approximately $1.95 \%$ at 5.6 mbsf (Fig. 3). Below this depth, organic carbon increases significantly to approximately $2.9 \%$ at $8.25 \mathrm{mbsf}$ before rapidly decreasing again to a local minimum of $1.95 \%$ at 12.85 mbsf (Fig. 3). Between 12.85 and 68 mbsf, organic carbon concentrations remain a more-or-less constant $1.6 \%$. The subsurface increase in organic carbon at 8.25 mbsf may be reflected in a slowing down in the depth-related decrease in the total bacterial population in the same interval (Fig. 2), but this change is not statistically significant.

More interestingly, the base of the zone of rapidly decreasing organic carbon concentration at the bottom of the subsurface peak, at $12.85 \mathrm{mbsf}$, is coincident with the change in the rate of bacterial population decrease with depth. It is possible that this represents a switch from bioavailable organic carbon in the upper layers of the sediment to more recalcitrant organic carbon below this depth. In a similar study of the Peru Margin by Parkes et al. (1993) total numbers of bacteria decreased rapidly to approximately $4 \mathrm{mbsf}$ and then more gradually to $80 \mathrm{mbsf}$. An increasing proportion of the organic matter with depth was uncharacterized (total organic carbon minus that attributable to carbohydrate, lipid, and protein; Parkes et al., 1993), and the amount of uncharacterized organic matter was negatively correlated with the total count. Parkes et al. (1993) postulated that a proportion of the uncharacterized organic matter was derived from dead bacteria or bacterial "necromass," which was relatively recalcitrant. An accumulation of such recalcitrant material during the utilization of bioavailable carbon in SBB sediments could result in the abrupt changes observed in direct and dividing cell count profiles (Fig. 2).

Rapid removal of bioavailable organic carbon in similarly anoxic environments has been shown at Cape Lookout Bight, an organicrich lagoon in South Carolina, where the organic carbon flux to the sediment was estimated at $149 \mathrm{~mol} / \mathrm{m}^{2} / \mathrm{yr}$, resulting in a surface sediment organic carbon concentration of $3 \%-4 \%$. Twenty-four percent of the sedimenting carbon was recycled back into the overlying water as "metabolizable" carbon via methanogenesis and sulfate reduction with a mean residence time of 4.3 months, and a total remineralization time of bioavailable carbon was estimated at 3 years (Martens and Klump, 1984). Additionally, analysis of SBB sediments associated with the Beggiatoa mat community has indicated that the microbial mat is degraded within $1 \mathrm{~cm}$ of the sediment surface and completely removed by $4 \mathrm{~cm}$ (Grant, 1991). High levels of degradative bacterial activity and organic carbon recycling, increasing the relative recalcitrance of the in situ organic carbon, would also help to explain the comparatively high levels of organic carbon that are preserved in the deep SBB sediments, an observation that has also been reported for the Peru Margin (Fossing, 1990; Parkes et al., 1993).

Methane concentrations in SBB sediments rise from $35 \mu \mathrm{mol} / \mathrm{L}$ at $1.5 \mathrm{mbsf}$ to a maximum of over $4100 \mu \mathrm{mol} / \mathrm{L}$ at $9.0 \mathrm{mbsf}$ before decreasing (Fig. 3). Below $17.5 \mathrm{mbsf}(1400 \mu \mathrm{mol} / \mathrm{L})$, concentrations remain reasonably constant with depth. There is a gradual decrease to a minimum $(560 \mu \mathrm{mol} / \mathrm{L})$ at $45 \mathrm{mbsf}$, and the higher concentrations $(1500 \mu \mathrm{mol} / \mathrm{L})$ are associated with sand layers around $60 \mathrm{mbsf}$. This is comparable with $200-300 \mu \mathrm{mol} / \mathrm{L}$ reported in the upper $2 \mathrm{~m}$ of SBB sediments (Kosiur and Warford, 1979; Doose and Kaplan, 1981). It is likely that the maximum concentration we report here is not the actual maximum for the site, as methane maxima usually occur close to the base of the sulfate reduction zone (approximately 2 mbsf, see below), a depth interval for which we have no methane data. Maximum methane concentrations of $9500,12,300$, and 10,700 $\mu \mathrm{mol} / \mathrm{L}$ have been recorded at $2.7,3.8$, and $5.7 \mathrm{mbsf}$, respectively, in SBB sediments (Barnes and Goldberg, 1976; Warford et al., 1979; Kosiur and Warford, 1979; Doose and Kaplan 1981). These were related to pore water concentrations of sulfate, which decreased from $27.6 \mathrm{mmol} / \mathrm{L}$ at the surface to 0 between 1.5-2 mbsf (Kosiur and Warford, 1979; Doose and Kaplan, 1981), concomitant with an increase in reduced sulfur species (Warford et al., 1979; Schimmelmann and Kastner, 1993). Although no interstitial water sulfate data were available for this core, sulfate depth profiles are likely to be similar to those in the above previous studies.

The presence of methane with high $\mathrm{C}_{1} / \mathrm{C}_{2+}$ ratios $(>50,000)$ throughout Hole $893 \mathrm{~B}$ indicates a biogenic origin. Nevertheless this is an area with abundant seeps of oil and gas (Kennett, Baldauf, et al. 1994), and a thermogenic component at greater depth cannot be excluded. In Hole $893 \mathrm{~A}$, methane concentrations at the near-surface were, like those of Hole $893 \mathrm{~B}$, also in excess of $4000 \mu \mathrm{mol} / \mathrm{L}$, and at $175.6 \mathrm{mbsf}$ they were still approximately $1200 \mu \mathrm{mol} / \mathrm{L}$ (data not shown) with organic carbon concentrations remaining relatively constant $\left(1.5 \%-2.0 \% ; 165-195\right.$ mbsf; data not shown). The $\mathrm{C}_{1} / \mathrm{C}_{2+}$ ratios, however, remained high, averaging 21,700 between 100 and 175.6 mbsf, suggesting a continued biogenic source of methane at all depths sampled.

\section{SUMMARY}

Bacterial enumeration of SBB sediments has demonstrated high total and dividing cell counts consistent with the high organic carbon environment. Absolute bacterial numbers in near-surface sediment agree with an emerging relationship between surficial numbers of 
bacteria and overlying water depth. Both total count and dividing cell count decrease rapidly to approximately $13 \mathrm{mbsf}$ and then more gradually to $68.3 \mathrm{mbsf}$. The reason for the sudden change at $13 \mathrm{mbsf}$ is unclear but may be due to an alteration in the bioavailability of organic carbon. Near-surface organic carbon concentrations are less than those encountered in Peru Margin sediments but greater than those measured in Japan Sea sediments. Surface organic carbon concentrations of approximately $3.6 \%$ decrease rapidly to $2.0 \%$ at $13 \mathrm{mbsf}$ and then remain at $1.5 \%-2.0 \%$ to the base of the hole at $68.3 \mathrm{mbsf}$, suggesting that a considerable proportion of the organic carbon actually incorporated into the sediment is recalcitrant. Methane concentrations are high at the surface and are probably biogenic in origin. At greater depths, methane concentrations, although lower, remain substantial and the $\mathrm{C}_{1} / \mathrm{C}_{2+}$ ratio indicates a mainly biogenic source.

\section{ACKNOWLEDGMENTS}

This work was conducted while R.J. Parkes, J.C. Fry, A.J. Weightman, and J.R. Maxwell, were in receipt of a research grant (GST/02/683) from the Natural Environment Research Council, United Kingdom. We thank Drs. S. Bale and P. Wellsbury for constructive comments on a draft manuscript. We acknowledge the support and facilities provided by Bristol University and The University of Wales, Cardiff. We are grateful to the Ocean Drilling Program for providing samples from Leg 146.

\section{REFERENCES}

Balkwill, D.L., 1989. Numbers, diversity and morphological characteristics of aerobic chemoheterotrophic bacteria in deep subsurface sediments from a site in South Carolina. Geomicrobiol. J., 7:33-52.

Barnes, R.O., and Goldberg, E.D., 1976. Methane production and consumption in anoxic marine sediments. Geology, 4:297-300.

Belyaev, S.S., and Ivanov, M.V., 1983. Bacterial methanogenesis in underground waters. In Hailberg. R. (Ed.), Environ. Geochem. Ecol. Bull., 35:273-280.

Bernhard, J.M., and Reimers, C.E., 1991. Benthic foraminiferal population fluctuations related to anoxia: Santa Barbara basin. Biogeochemistry, $15: 127-149$.

Bianchi, A., 1986. Heterotrophic bacterial types surviving in the Quaternary and upper Pliocene sediments of the Mahakam Delta. C. R. Acad. Sci. Ser. 3, 303:449-451.

Chapelle, F.H., and Lovley, D.R., 1990. Rates of microbial metabolism in deep coastal plain aquifers. Appl. Environ. Microbiol., 56:1865-1874.

Cragg, B.A., 1994. Bacterial profiles in deep sediment layers from the Lau Basin (Site 834). In Hawkins, J.. Parson, L., Allan, J., et al., Proc. ODP, Sci. Results, 135: College Station, TX (Ocean Drilling Program), 147150.

Cragg, B.A., Harvey, S.M., Fry, J.C., Herbert, R.A., and Parkes, R.J., 1992. Bacterial biomass and activity in the deep sediment layers of the Japan sea, Hole 798B. In Pisciotto, K.A., Ingle, J.C., Jr., von Breymann, M.T., Barron, J., et al., Proc. ODP, Sci. Results., 127/128 (Pt. 1): College Station, TX (Ocean Drilling Program), 761-776.

Cragg, B.A., and Kemp. A.E.S., in press. Bacterial profiles in deep sediment layers from the Eastern Equatorial Pacific Ocean, Site 851. In Pisias, N.G., Mayer, L.A., Janecek, T.R., and van Andel, T.H. (Eds.), Proc. ODP, Sci. Results, 138: College Station, TX (Ocean Drilling Program).

Cragg, B.A., Parkes, R.J., Fry, J.C., Herbert, R.A., Wimpenny, J.W.T., and Getliff, J.M., 1990. Bacterial biomass and activity profiles within deep sediment layers. In Suess, E., von Huene, R., et al., Proc. ODP, Sci. Results, 112: College Station, TX (Ocean Drilling Program), 607-619.

Craven, D.B., Jahnke, R.A., and Carlucci, A.F., 1986. Fine-scale vertical distributions of microbial biomass and activity in California Borderland sediments. Deep-Sea Res., 33:379-390.

Davis, J.B., 1967. Petroleum Microbiology: Amsterdam (Elsevier).

Doose, P.R., and Kaplan, I.R., 1981. Biogenetic control of gases in marine sediments of Santa Barbara Basin, California. AAPG Bull., 65:919-920.

Erlich, H.L., and Ghiorse, W.C. (Eds.), 1989. Deep Subsurface Microbiology. Geomicrobiol. J., Spec. Iss. 7.
Fliermans, C.B., McKinsey, P.C., and Franck, M.M., 1993. Microbial activities in southeastern coastal plain sediments to depths of 3800 feet. Abstr. Int. Symp. Subsurf. Microbiol., B34.

Fossing, H., 1990. Sulfate reduction in shelf sediments in the upwelling region off Central Peru. Cont. Shelf Res., 10:355-367.

Fry, J.C., 1988. Determination of biomass. In Austin, B. (Ed.), Methods in Aquatic Bacteriology: Chichester (Wiley), 27-72.

Getliff, J.M., Fry, J.C., Cragg, B.A., and Parkes, R.J., 1992. The potential for bacteria growth in deep sediment layers of the Japan Sea, Hole 798BLeg 128. In Pisciotto, K.A., Ingle, J.C., Jr., von Breymann, M.T., Barron, J., et al., Proc. ODP, Sci. Results, $127 / 128$ (Pt. 1): College Station, TX (Ocean Drilling Program), 755-760.

Goulder, R., 1977. Attached and free bacteria in an estuary with abundant suspended solids. J. Appl. Bacteriol., 43:399-405.

Grant, C.W., 1991. Lateral and vertical distributions and textural features of filamentous bacterial (Beggiatoa sp.) mats in Santa Barbara Basin, California. AAPG Bull., 75:585.

Ingle, J.C., Jr., Suyehiro, K., von Breymann, M.T., et al., 1990. Proc. ODP, Init. Repts., 128: College Station, TX (Ocean Drilling Program).

Isaacs, C.M., 1985. Abundance versus rates of accumulation in fine-grained strata of the Miocene Santa Barbara Basin, California. Geo-Mar. Lett., 5:25-30.

Jørgensen, B.B., 1983. Processes at the sediment/water interface. In Bolin, B., and Cook, R.B. (Eds.), The Major Biogeochemical Cycles and Their Interactions: Chichester (Wiley), 477-515.

Jørgensen, B.B., Bang, M., and Blackburn, T.H., 1990. Anaerobic mineralization in marine sediments from the Baltic Sea-North Sea transition. Mar. Ecol. Prog. Ser., 59:39-54.

Kennedy, J.A., and Brassell, S.C., 1992. Molecular records of twentieth century El-Niño events in laminated sediments from the Santa Barbara basin. Nature, 357:62-64.

Kennett, J.P., Baldauf, J.G., et al., 1994. Proc. ODP, Init. Repts., 146 (Pt. 2): College Station, TX (Ocean Drilling Program).

Kosiur, D.R., and Warford, A.L., 1979. Methane production and oxidation in Santa Barbara basin sediments. Estuarine Coastal Shelf Sci., 8:379-385.

Krumbein, W.E., 1983. Microbial Geochemistry: Oxford (Blackwell Sci.).

Lange, C.B., Berger, W.H., Burke, S.K., Casey, R.E., Schimmelmann, A., Soutar, A., and Weinheimer, A.L., 1987. El Niño in Santa Barbara basin: diatom, radiolarian, and foraminiferan responses to the "1983 El Nino" event. Mar. Geol., 78:153-160.

Lochte, K., and Turley, C.M., 1988. Bacteria and cyanobacteria associated with phytodetritus in the deep sea. Nature, 333:67-69.

Martens, C.S., and Klump, J.V., 1984. Biogeochemical cycling in an organic-rich coastal marine basin, 4 : an organic carbon budget for sediments dominated by sulfate reduction and methanogenesis. Geochim. Cosmochim. Acta, 48:1987-2004.

Mayer, L., Pisias, N., Janecek, T., et al., 1992. Proc. ODP, Init. Repts., 138 (Pts. 1 and 2): College Station, TX (Ocean Drilling Program).

Novitsky, J.A., and Karl, D.M., 1986. Characterization of microbial activity in the surface layers of a coastal sub-tropical sediment. Mar. Ecol. Prog. Ser., 28:49-55.

Oremland, R.S., Culbertson, C., and Simoneit, B.R.T., 1982. Methanogenic activity in sediment from Leg 64, Gulf of California. In Curray, J.R., Moore, D.G., et al., Init. Repts. DSDP, 64 (Pt. 2): Washington (U.S. Govt. Printing Office), 759-762.

Parkes, R.J., Cragg, B.A., Bale, S.J., Getliff, J.M., Goodman, K., Rochelle, P.A., Fry, J.C., Weightman, A.J., and Harvey, S.M., 1994. Deep bacterial biosphere in Pacific Ocean sediments. Nature, 371:410-413.

Parkes, R.J., Cragg, B.A., Fry, J.C., Herbert, R.A., and Wimpenny, J.W.T., 1990. Bacterial biomass and activity in deep sediment layers from the Peru margin. Philos. Trans. R. Soc. London A, 331:139-153.

Parkes, R.J., Cragg, B.A., Getliff, J.M., Harvey, S.M., Fry, J.C., Lewis, C.A., and Rowland, S.J., 1993. A quantitative study of microbial decomposition of biopolymers in Recent sediments from the Peru Margin. Mar. Geol., 113:55-66.

Parson, L., Hawkins, J., Allan, J., et al., 1992. Proc. ODP, Init. Repts., 135: College Station, TX (Ocean Drilling Program).

Patience, R.L., Clayton, C.J., Kearsley, A.T., Rowland, S.J., Bishop, A.N., Rees, A.W.G., Bibby, K.G., and Hopper, A.C., 1990. An integrated biochemical, geochemical, and sedimentological study of organic diagenesis in sediments from Leg 112. In Suess, E., von Huene, R., et al., Proc. ODP, Sci. Results, 112: College Station, TX (Ocean Drilling Program), $135-153$. 


\section{B.A. CRAGG ET AL.}

Phelps, T.J., Fliermans, C.B., Garland, T.R., Pfiffner, S.M., and White, D.C., 1989. Methods for recovery of deep terrestrial subsurface sediments for microbiological studies. J. Microbiol. Methods, 9:267-279.

Reimers, C.E., Lange, C.B., Tabak, M., and Bernhard, J.M., 1990. Seasonal spillover and varve formation in the Santa Barbara Basin, California. Limnol. Oceanogr., 35:1577-1585.

Rittenberg, S., 1940. Bacteriological analysis of some long cores of marine sediments. J. Mar. Res., 3:191-201.

Savrda, C.E., Bottjer, D.J., and Gorsline, D.S., 1984. Development of a comprehensive oxygen-deficient marine biofacies model: evidence from Santa Monica, San Pedro, and Santa Barbara Basins, California Continental Borderland. AAPG Bull., 68:1179-1192.

Schimmelmann, A., and Kastner, M., 1993. Evolutionary changes over the last 1000 years of reduced sulfur phases and organic carbon in varved sediments of the Santa Barbara Basin, California. Geochim. Cosmochim. Acta, 57:67-78

Schimmelmann. A., Lange, C.B., and Berger, W.H., 1990. Climatically controlled marker layers in Santa Barbara basin sediments, and fine-scale core-to-core correlation. Limnol. Oceanogr., 35:165-173.

Schimmelmann, A., Lange, C.B., Berger, W.H., Simon, A., Burke, S.K., and Dunbar, R.B., 1992. Extreme climatic conditions recorded in Santa Barbara basin laminated sediments: the 1835-1840 Macoma event. Mar. Geol., 106:279-299.

Schimmelmann, A., and Tegner, M.J., 1991. Historical oceanographic events reflected in ${ }^{13} \mathrm{Cl}^{12} \mathrm{C}$ ratio of total organic carbon in laminated Santa Barbara basin sediment. Global Biogeochem. Cycles, 5:173-188.

Schmidt, H., and Reimers, C.E., 1991. The recent history of trace metal accumulation in the Santa Barbara Basin, southern Californian borderland. Estuarine Coastal Shelf Sci., 33:485-500.

Sholkovitz, E., 1973. Interstitial water chemistry of the Santa Barbara Basin sediments. Geochim. Cosmochim. Acta, 37:2043-2073.

Soutar, A., and Crill, P.A., 1977. Sedimentation and climatic patterns in the Santa Barbara Basin during the 19th and 20th centuries. Geol. Soc. Am. Bull., 88:1161-1172.

Stax, R., and Stein, R., 1993. Long-term changes in the accumulation of organic carbon in Neogene sediments, Ontong Java Plateau. In Berger,
W.H., Kroenke, L.W., Mayer, L.A., et al., Proc. ODP, Sci. Results, 130: College Station, TX (Ocean Drilling Program), 573-584.

Suess, E., von Huene, R., et al., 1988. Proc. ODP. Init. Repts., 112: College Station, TX (Ocean Drilling Program).

Tarafa, M.E., Whelan, J.K., Oremland, R.S., and Smith, R.L., 1987. Evidence of microbiological activity in Leg 95 (New Jersey Transect) sediments. In Poag, C.W., Watts, A.B., et al., Init. Repts. DSDP, 95: Washington (U.S. Govt. Printing Office), 635-640.

ten Haven, H.L., Littke, R., Rullkötter, J., Stein, R., and Welte, D.H., 1990. Accumulation rates and composition of organic matter in late Cenozoic sediments underlying the active upwelling area off Peru. In Suess, E., von Huene, R., et al., Proc. ODP, Sci. Results, 112: College Station, TX (Ocean Drilling Program), 591-606.

Thornton, S.E., 1986. Origin of mass flow sedimentary structures in hemipelagic basin deposits: Santa Barbara Basin, California borderland. GeoMar. Lett., 6:15-19.

Turley, C.M., and Lochte, K., 1990. Microbial response to the input of fresh detritus to the deep-sea bed. Palaeogeogr., Palaeoclimatol., Palaeoecol., $89: 3-23$.

Warford. A.L., Kosiur, D.R., and Doose, P.R., 1979. Methane production in Santa Barbara basin sediments. Geomicrobiol. J., 1:117-137.

Whelan. J.K., Oremland, R., Tarafa, M., Smith, R., Howarth, R., and Lee, C., 1986. Evidence for sulfate-reducing and methane producing microorganisms in sediments from Sites 618, 619, and 622. In Bouma, A.H., Coleman, J.M., Meyer, A.W., et al., Init. Repts. DSDP, 96: Washington (U.S. Govt. Printing Office), 767-775.

White, D.C., Fredrickson, H.F., Gehron, M.H., Smith, G.A., and Martz, R.F, 1983. The groundwater aquifer microbiota: biomass, community structure and nutritional status, Dev. Ind. Microbiol., 24:189-199.

ZoBell, C.E., 1958. Ecology of sulfate reducing bacteria. Prod. Mon., 22:I229.

Date of initial receipt: 23 August 1994

Date of acceptance: 11 January 1995

Ms 146SR-302 